\title{
Sistem Monitoring Tanah Longsor Berbasis Internet of Things dan Geographic Information System
}

Roni Wahyu Putra, Haris Suryamen M.Sc

Fakultas Teknologi Informasi Universitas Andalas, Kampus Limau Manis, Padang, 25163, Indonesia

\section{ARTICLE INFORMATION}

Received: July $7^{\text {th }}, 2019$

Revised: September $4^{\text {th }}, 2019$

Available online: September $30^{\text {th }}, 2019$

\section{KEYWORDS}

Landslide, Rainfall, Soil Moisture, Soil Displacement.

\section{CORRESPONDENCE}

E-mail: haris.suryamen@ fti.unand.ac.id

\section{A B S T R A C T}

Landslide is one of the natural disasters that happens quite often in many parts of Indonesia. Landslide brings negative aspects to people because it causes material loss and loss of life. Landslides generally occur in the rainy season with high rainfall. In this research, a system is made to predict the chance of landslide to happen by measuring the level of rainfall, soil moisture, and soil displacement, and send the sensor data and position of a landslide to the database. According to this research, the system can predict the chance for the landslide to happen and give a warning with a $100 \%$ success rate.

\section{PENDAHULUAN}

Longsor merupakan salah satu bencana alam yang kerap terjadi di berbagai daerah di Indonesia[1]. Peristiwa longsor berdampak negatif bagi masyarakat karena dapat menyebabkan kerugian materil dan korban jiwa, contohnya longsor dapat mengakibatkan kendaraan tertimbun oleh tanah sehingga menyebabkan korban jiwa. Hal ini dikarenakan tidak adanya informasi tentang kondisi jalan pada saat kendaraan itu lewat. Dilaporkan oleh media online Antaranews, longsor terjadi di Lubuak Paraku KM17, Kecamatan Lubuk Kilangan, Kota Padang, Sumatera Barat (Sumbar), mengakibatkan material longsor menutupi jalan nasional PadangSolok sehingga tidak dapat dilalui kendaraan yang disebabkan oleh hujan deras yang mengguyur Kota Padang sejak Sabtu siang hingga Minggu pagi[2].

Tanah longsor umumnya terjadi pada musim hujan dengan curah hujan yang tinggi. Hujan menyebabkan kadar air pada tanah meningkat sehingga area yang tidak ada atau sedikit tutupan lahannya akan semakin mudah terjadi longsor.

Pada penelitian sebelumnya [3] mengenai sistem peringatan dini bencana longsor, pada penilitian tersebut dapat mendeteksi getaran tanah dan kelembaban tanah dimana hasilnya tersimpan pada file penyimpanan dan jika terdeteksi getaran tanah dan kelembaban tanah lebih dari 51\% akan terkirim notifikasi bahaya ke smartphone namun sistem tidak dapat mendeteksi lokasi terjadinya longsor.

Berdasarkan penelitian sebelumnya, diperlukan sistem yang dapat memperkirakan tingkat kemungkinan tanah longsor dengan Internet of Things (IoT) sebagai sarana komunikasi dan Geographic Information System (GIS) yang mampu menyediakan informasi data seperti geospasial, objek di permukaan bumi secara cepat, sehingga dapat dilakukan upaya mitigasi yang bertujuan untuk mengurangi efek dari bencana ketika bencana itu terjadi.

Sistem mengunakan sensor rain gauge, sensor soil moisture, Potensiometer. Sensor-sensor berfungsi menghitung curah hujan, kelembaban tanah, dan pergeseran tanah yang akan diproses oleh mikrokontroler untuk menentukan klasifikasi ancaman longsor. Mikrokontroler dan sensor-sensor ditempatkan di sekitar area rawan longsor. Sistem akan memberikan input data berdasarkan klasifikasi ancaman ke Geographic Information System (GIS), sehingga GIS dapat menampilkan koordinat dan klasifikasi ancaman kepada Badan Penanggulangan Bencana Daerah (BPBD) dan masyarakat. Dengan adanya sistem ini, diharapkan Badan Penanggulangan Bencana Daerah (BPBD) dan masyarakat 
dapat dengan mudah mengetahui keadaan area jalan sehingga dapat menghindari kerugian akibat longsor.

\section{Penyebab Longsor}

Longsor adalah salah satu bentuk bencana alam yang diakibatkan oleh gerakan massa tanah yang sangat berlebihan menyebabkan gerakan melorot ke bawah, longsor biasanya terjadi pada daerah perbukitan di daerah tropis basah. Gerakan massa umumnya disebabkan oleh gaya-gaya gravitasi dan kadang-kadang getaran atau gempa juga menyokong kejadian tersebut.[1]

Banyak faktor, seperti kondisi-kondisi geologi dan hidrologi, topografi, iklim dan perubahan cuaca mempengaruhi stabilitas lereng yang mengakibatkan terjadinya longsor. Sebab-sebab alami yang menggangu kestabilan lereng, contohnya : pelapukan, hujan lebat atau hujan tidak begitu lebat tapi berkepanjangan, adanya lapisan lunak dan lain-lain. Sebab-sebab yang terkait dengan aktifitas manusia, contohnya : penggalian di kaki lereng, pembangunan di permukaan lereng dan lain-lain. [1]

\section{Arduino UNO}

Arduino UNO merupakan papan mikrokontroler berbasiskan Atmega328, memiliki 14 pin digital input/output (6 di anataranya bisa digunakan untuk output PWM), dan 6 pin analog.

Papan Arduino UNO dapat beroperasi pada suplai tengan 6v sampai 20v. Jika suplai yang masuk kecil dari $7 \mathrm{v}$ maka pin $5 \mathrm{v}$ pada Arduino UNO mungkin akan mensuplai tegangan kecil dari $5 \mathrm{v}$ dan jika suplai yang masuk besar dari 12v maka Arduino UNO akan menjadi tidak stabil, capat panas, dan merusak papan Arduino UNO. Seperti yang terlihat pada Gambar 1.

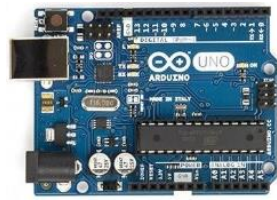

\section{Gambar 1. Arduino UNO}

\section{Sensor Rain Gauge}

Sensor rain gauge adalah alat pengukur hujan yang digunakan untuk mengumpulkan dan mengukur hujan selama periode tertentu.

Sensor rain gauge mengukur curah hujan dengan intensitas hingga lima inci per jam dengan resolusi 0,01 inci, dan akurasi $1 \%$ untuk tingkat curah hujan sampai 1 inci per jam. Mekanisme tapping bucket dipasang pada poros stainless steel dengan bantalan kuningan[5]. Seperti yang terlihat pada Gambar 2.

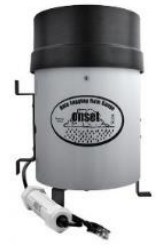

\section{Gambar 2. Sensor Rain Gauge}

\section{Sensor Soil Moisture}

Sensor soil moisture yaitu sensor yang mampu mendeteksi intensitas air di dalam tanah. Sensor soil moisture terdiri dari dua probe untuk melewatkan arus melalui tanah, kemudian membaca resistansi untuk mendapatkan nilai tingkat kelembaban. Semakin banyak air maka tanah akan semakin mudah menghantarkan listrik. Kedua probe merupakan media yang akan menghantarkan tegangan analog yang nilainya relatif kecil. Tegangan ini nantinya akan diubah menjadi tegangan digital untuk diproses[6]. Seperti yang terlihat pada Gambar 3.

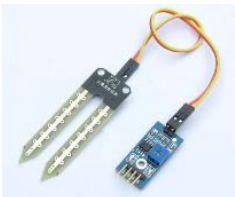

\section{Gambar 3. Sensor Soil Moisture}

\section{Potensiometer}

Potensiometer adalah resistor tiga terminal dengan sambungan geser yang membentuk pembagi tegangan dapat disetel. Jika hanya dua terminal yang digunakan (salah satu terminal tetap dan terminal geser), potensiometer berperan sebagai resitor variabel atau Rheostat. Potensiometer biasanya digunakan untuk mengendalikan peranti elektronik seperti pengendali suara pada penguat. Potensiometer yang dioperasikan oleh suatu mekanisme dapat digunakan sebagai tranducer[7]. Seperti yang terlihat pada Gambar 4.

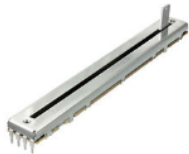

\section{Gambar 4. Potensiometer}

\section{Modul Global System for Mobile (GSM)}

Modul GSM adalah suatu teknologi komunikasi seluler yang menggunakan teknik digital. Teknologi GSM banyak di gunakan pada komunikasi bergerak khususnya handphone. Teknologi ini memanfaatkan gelombang mikro dan pengiriman sinyal yang dibagi berdasarkan waktu, sehingga sinyal yang dipancarkan dari pengirim akan sampai pada penerima. Seperti yang terlihat pada Gambar 5.

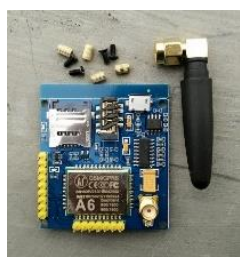

Gambar 5. Modul GSM

\section{Geographic Information System (GIS)}

GIS adalah suatu sistem berbasis komputer yang memberi 4 (empat) kemampuan untuk menangani data bereferensi geografi, 
yaitu meliputi pemasukan, pengolahan atau manajemen data (penyimpanan atau pemanggilan kembali), manipulasi dan analisis serta keluaran. Di dalam GIS data tersimpan dalam format digital, jumlah data yang besar dapat tersimpan dan diambil kembali secara cepat dan efisien. Keunggulan GIS lainnya adalah kemampuan memanipulasi data dan analisis data spasial dengan mengaitkan data atau informasi atribut untuk menyatukan tipe data yang berbeda kedalam suatu analisis tunggal[9].

\section{Internet of Things (IoT)}

Internet of Things adalah sebuah teknologi yang memungkinkan kita untuk menghubungkan mesin, peralatan dan benda fisik lainnya dengan sensor jaringan dan aktuator untuk memperoleh data dan mengelola kinerjanya sendiri, sehingga memungkinkan mesin untuk berkolaborasi dan bahkan bertindak berdasarkan informasi baru yang diperoleh secara independen. IoT merupakan sebuah konsep yang bertujuan untuk memperluas manfaat dari konektivitas internet yang tersambung secara terusmenerus[10].

\section{Sirine}

Sirine didefinisikan sebagai sebuah bunyi peringatan atau pemberitahuan. Dalam istilah jaringan, dapat didefinisikan sebagai sebuah pesan yang berisikan pemberitahuan ketika terjadi penurunan atau kegagalan dalam penyampaian sinyal komunikasi data ataupun ada peralatan yang mengalami kerusakan (penurunan kinerja). Pesan ini digunakan untuk memperingatkan operator atau administrator mengenai adanya masalah (bahaya) pada jaringan.

Sirine merupakan Alarm yang digunakan untuk mengeluarkan bunyi peringatan tanda bahaya. Fungsi sirine adalah sebagai peringatan dini tsunami, sirine kebakaran dan lainnya. [11]. Seperti Gambar 6.

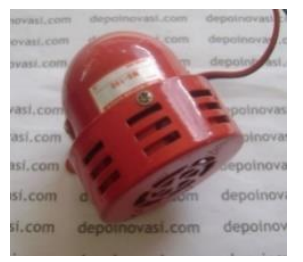

\section{Gambar 6. Sirine}

\section{GSM Triangulasi}

Triangulasi adalah sebuah metode yang dapat digunakan untuk menentukan posisi dari suatu perangkat dengan menggunakan perhitungan dari tiga buah BTS yang paling dekat dengan perangkat yang akan dilacak. Metode ini dapat dilakukan jika perangkat tersebut tersambung dengan BTS atau sedang melakukan komunikasi[12]. Seperti Gambar 7.

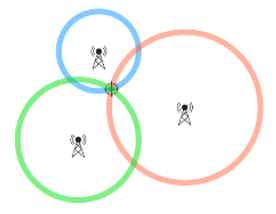

\section{Gambar 7. GSM Triangulasi}

\section{Universal Transverse Mercator ( UTM)}

UTM adalah proyeksi konformal menggunakan sistem koordinat cartesian 2 dimensi untuk memberikan lokasi di permukaan bumi. UTM adalah representasi posisi horizontal, yaitu digunakan untuk mengidentifikasi lokasi di bumi secara independen dari posisi vertikal.

Sistem UTM bukanlah proyeksi peta tunggal. Sistem ini malah membagi bumi menjadi enam puluh zona, masing-masing enam derajat bujur, dan menggunakan proyeksi mercator transversal garis potong di setiap zona[13]. Seperti yang terlihat pada Gambar 8 .

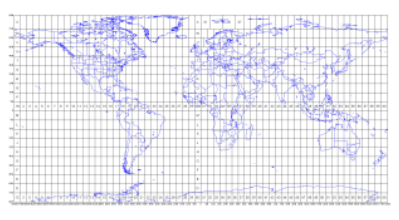

\section{Gambar 2.8 UTM}

\section{Relay}

Relay merupakan saklar (switch) yang dioperasikan secara listrik dan merupakan komponen elektromekanikal yang terdiri dari 2 bagian utama yakni elektromagnet (coil) dan mekanikal (seperangkat kontak saklar/switch). Relay menggunakan prinsip elektromagnetik untuk menggerakkan kontak saklar sehingga dengan arus listrik yang kecil (low power) dapat menghantarkan listrik yang bertegangan lebih tinggi. Relay bekerja berdasarkan elektromagnetik untuk menggerakkan sejumlah kontraktor yang tersusun atau sebuah saklar elekronis yang dapat dikendalikan dari rangkaian elekronik lainnya. Seperti yang terlihat pada Gambar 9.

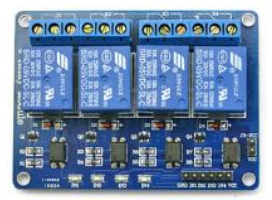


Gambar 9. Relay

\section{METODOLOGI PENELITIAN}

Pada penelitian ini metode yang digunakan adalah penelitian eksperimental (experimental research). Penelitian eksperimental adalah jenis penelitian untuk mendapatkan data dari beberapa kali percobaan. Penelitian yang dilakukan merupakan pembuatan sistem yang bertujuan untuk menyelesaikan permasalahan seperti yang telah dijabarkan sebelumnya.

\section{Rancangan Umum Sistem}

Rancangan umum Sistem Monitoring Longsor Berbasis Internet of Things dan Geographic Information System dapat dilihat pada Gambar 10 dan rangkaian sistem dapat dilihat pada Gambar 11.

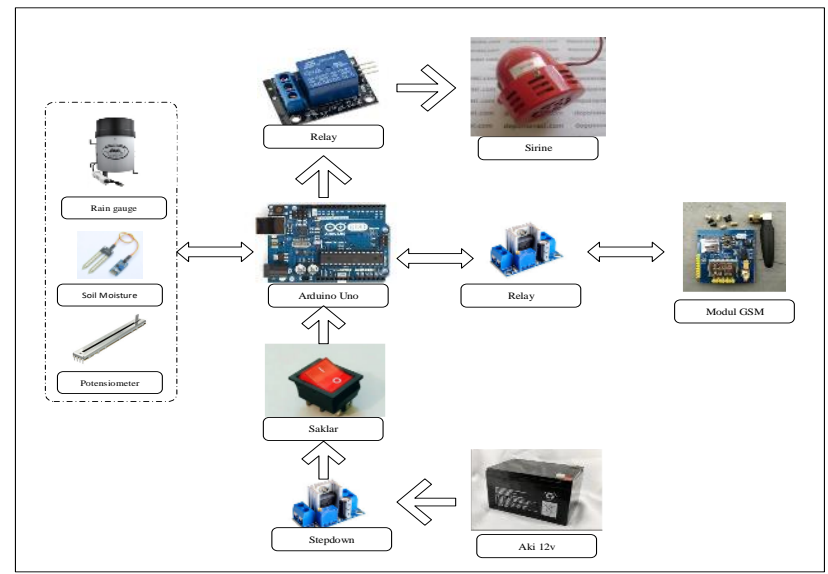

Gambar 10. Rangcangan Sistem Secara Umum

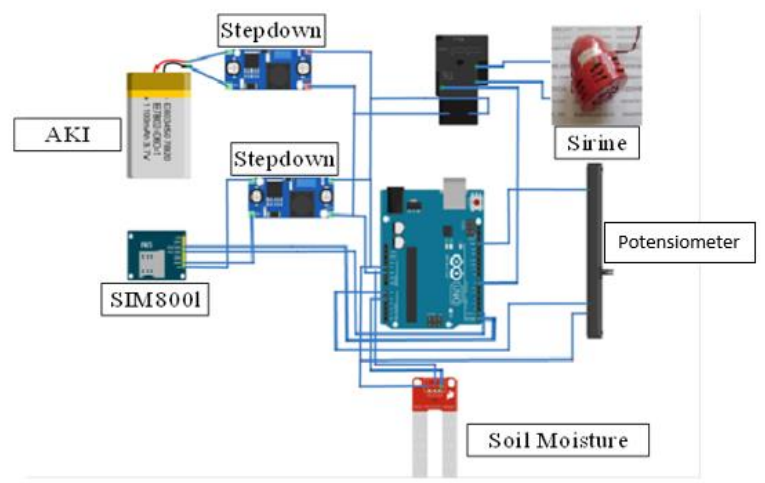

Gambar 11. Rangcangan Sistem

Berikut adalah prinsip kerja dari Sistem Monitoring Longsor Berbasis Internet of Things dan Geographic Information System:

1. Sensor Rain Gauge

Sensor rain gauge di letakan di atas permukaan tanah untuk mengukur intensitas hujan.

2. Sensor Siol Moisture
Sensor ini terletak di dalam lereng tanah dan akan berfungsi untuk mengukur kelembapan tanah.

3. Potensiometer

Potensiometer terletak di atas permukaan tanah untuk mengukur gerakan tanah.

4. Sirine

Sirine akan berfungsi untuk memberikan peringatan berdasarkan tingkat kemungkinan longsor.

5. Relay

Realay berfungsi untuk mengontrol pengapian sirine berdasarkan perintah mikrokontroler.

6. Step down

Step down berfungsi sebagai menurunkan tegangan yang masuk dari suplai.

7. Arduino Uno

Arduino Uno berfungsi mengontrol input data dari sensor gain gauge, sensor soil moisture, dan potensiometer dan memproses input tersebut.

8. Modul GSM

Data yang telah diterima dan diproses oleh Arduino Uno akan dikirim menggunakan Modul GSM.

\section{Rancangan Proses}

Sistem ini terdiri dari dua bagian utama, yaitu perangkat keras dan perangkat lunak. Perancangan sistem ini bertujuan untuk memahami alur jalannya sistem mulai dari pembacaan data hingga pengiriman data. Sistem ini dapat dilihat dari Gambar 12. 


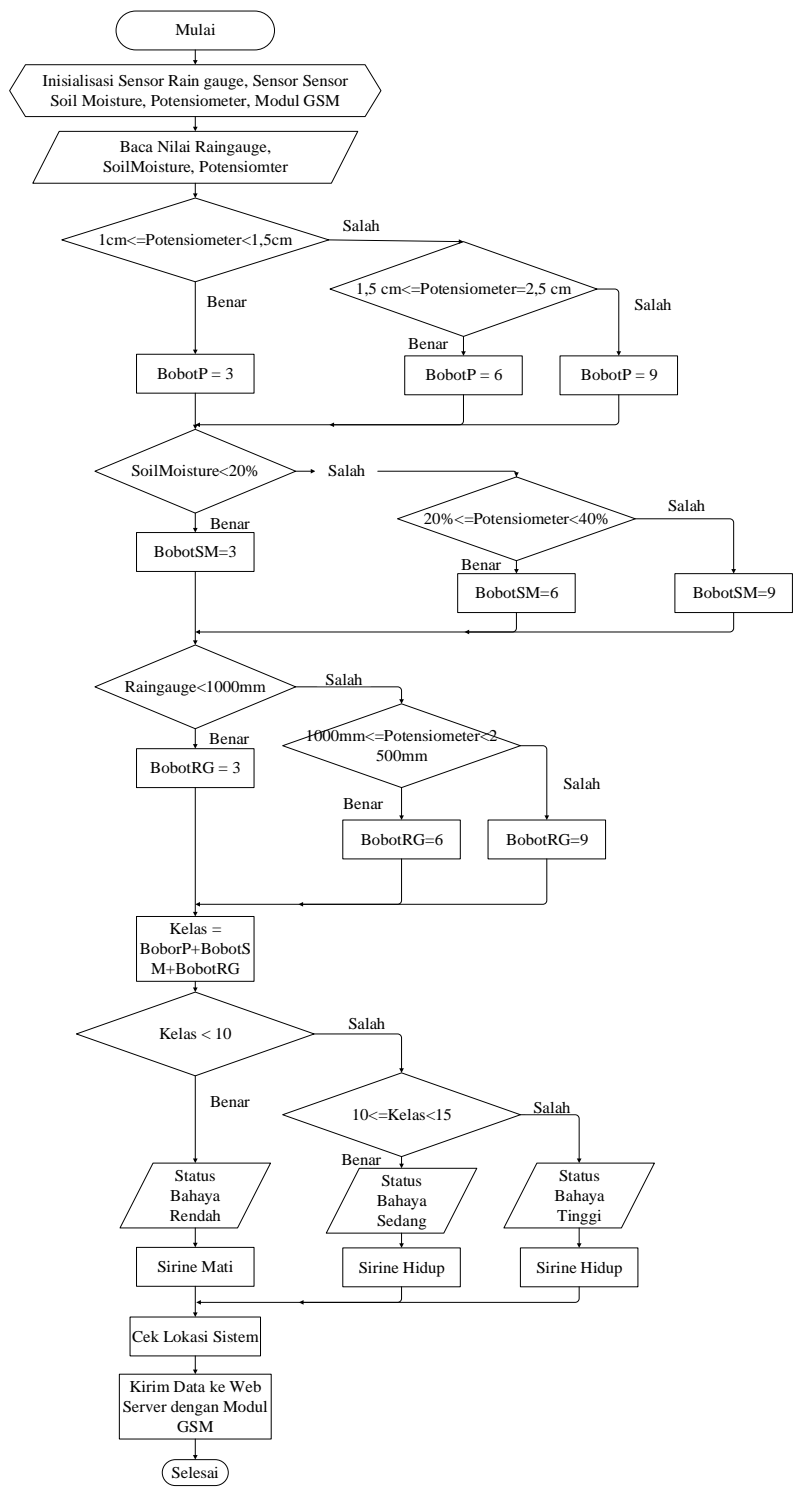

Gambar 12. Flowchart Rancangan Sistem

Gambar 12 menjelaskan bagaimana alur sistem secara keseluruhan, menunjukkan bahwa sistem ini dilengkapi dengan sensor rain gauge, sensor soil moisture, potensiometer, Arduino Uno, dan Modul GSM. Sensor rain gauge akan mengukur intensitas hujan, sensor soil moisture akan mengukur kelembaban tanah disekitar sistem ditempatkan dan jika terjadi pergeseran tanah maka potensiometer akan mengukur pergeseran tanah tersebut, selanjutnya mikrokontroler akan memproses input dari sensor dan Modul GSM mengirimkan data yang telah diproses ke database serta sirine akan hidup jika tingkat kemungkinan longsor berstatus waspada atau berbahaya. Data yang dikirimkan oleh Modul GSM akan menjadi input data yang akan di tampilkan pada GIS. Diagram blok proses pengiriman data dapat dilihat pada Gambar 13 dan pencarian titik lokasi sistem yang di rancang menggunakan GSM dapat di lihat pada Gambar 14.

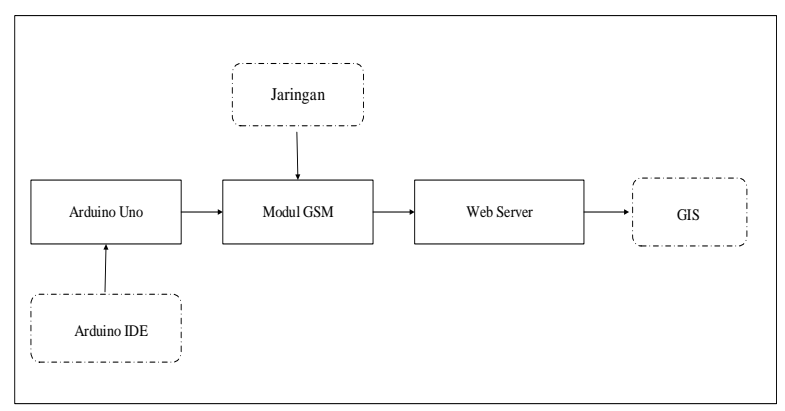

Gambar 13. Diagram Blok Proses Pengiriman Data

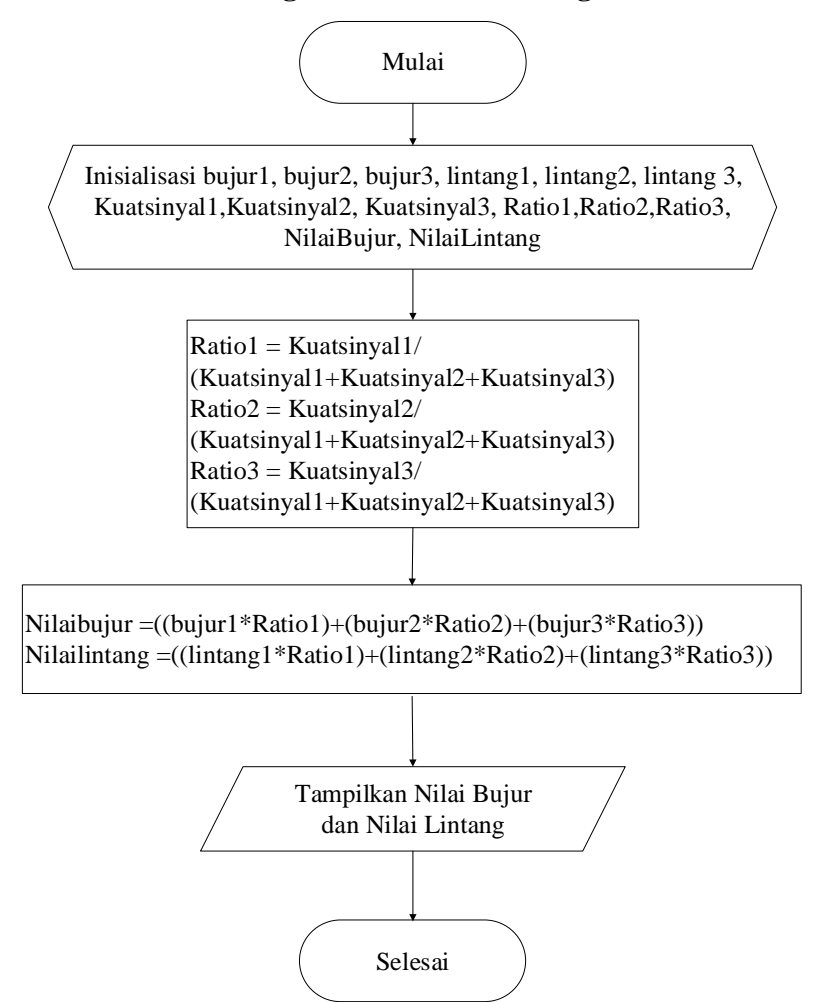

Gambar 14. Flowchart Mencari Lokasi

Perancangan Perangkat Keras

Pada tahapan ini dilakukan perancangan perangkar keras dari sistem untuk penelitian ini sehingga dapat dihasilkan Sistem Monitoring Longsor Berbasis Internet of Things dan Geographic Information System. Perancangan tersebut dapat dilihat pada Gambar 15 .

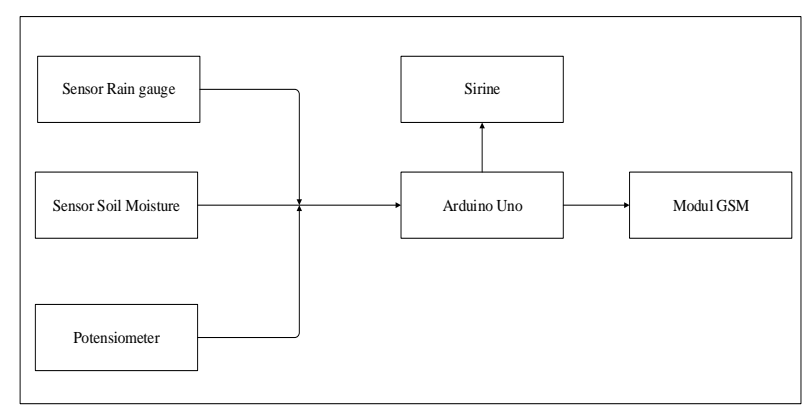

Gambar 15. Diagram Blok Perancangan Perangkat Keras 
Adapun penjelasan dari Diagram blok perangkat keras pada Gambar 3.6 adalah sebagai berikut:

1. Sensor rain gauge berfungsi mengukur intensitas hujan.

2. Sensor soil moisture berfungsi mengukur kelembaban tanah.

3. Potensimeter berfungsi untuk mendeteksi dan mengukur gerakan tanah.

4. Sirine berfungsi untuk memberikan peringatan.

5. Arduino Uno berfungsi sebagai pengontrol dari sistem ini.

6. Modul GSM berfungsi untuk mengirimkan data ke database.

\section{Perancangan Perangkat Lunak}

Perancangan perangkat lunak yang dibuat digunakan untuk mengatur kerja dari Mikrokontroler yang merupakan otak dari sistem dalam bentuk logika pemrograman, agar mikrokontroler dapat memproses masukan yang diberikan oleh sensor rain gauge, sensor soil moisture, dan potensiometer sehingga dapat menghasilkan output sesuai yang diinginkan dan dapat menjadi input data untuk GIS. Gambar 16 adalah flowchart dari Sistem Monitoring Longsor Berbasis Internet of Things dan Geographic Information System.

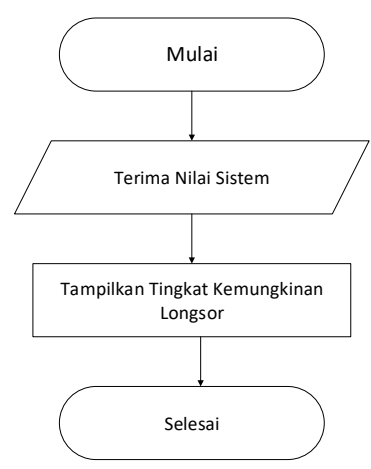

Gambar 16. Flowchart Perancangan Perangkat Lunak

\section{HASIL DAN PEMBAHASAN}

\section{Implementasi Perangkat Keras}

Sistem Monitoring Tanah Longsor berbasis Internet of Thing dan Geographic Information System ini menggunakan kotak dari akrilik berukuran $20 \times 15 \times 15 \mathrm{~cm}$ sebagai tempat komponenkomponen dirangkai. Sistem ini dibangun dengan menggunakan perangkat keras berupa sensor rain gauge, sensor soil moisture, potensiometer, mikrokontroler arduino UNO sebagai pengontrol sistem, relay yang berfungsi untuk menghidupkan atau mematikan pengapian untuk sirine, RTC sebagai jam pada sistem, SIM800L sebagai media komunikasi, step down untuk menurunkan tegangan dari aki ke arduino dan untuk menurunkan tegangan dari arduino ke modul GSM SIM800L , dan aki 12v sebagai sumber daya. Seperti yang terlihat pada Gambar 17.

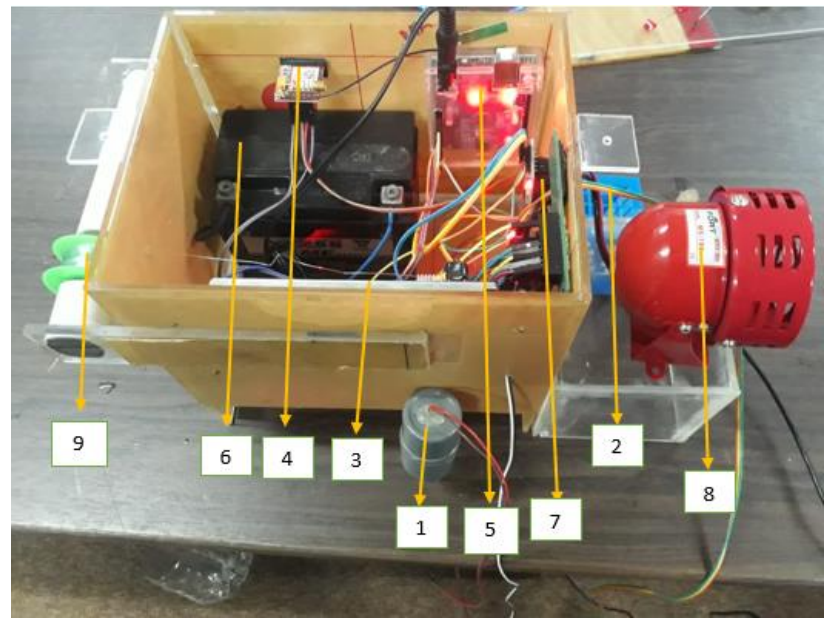

Gambar 17. Perangkat Keras Tampak Dalam Kotak

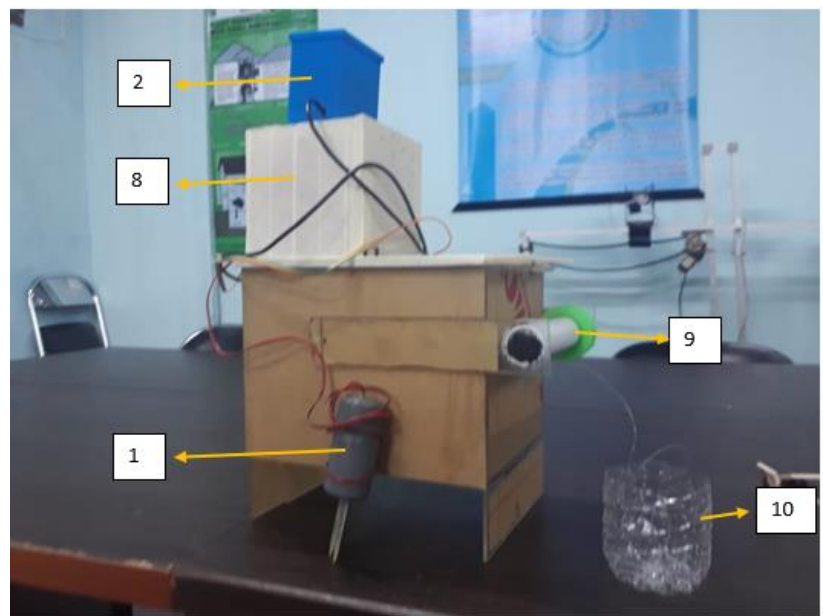

Gambar 18. Perangkat Keras Tampak Samping

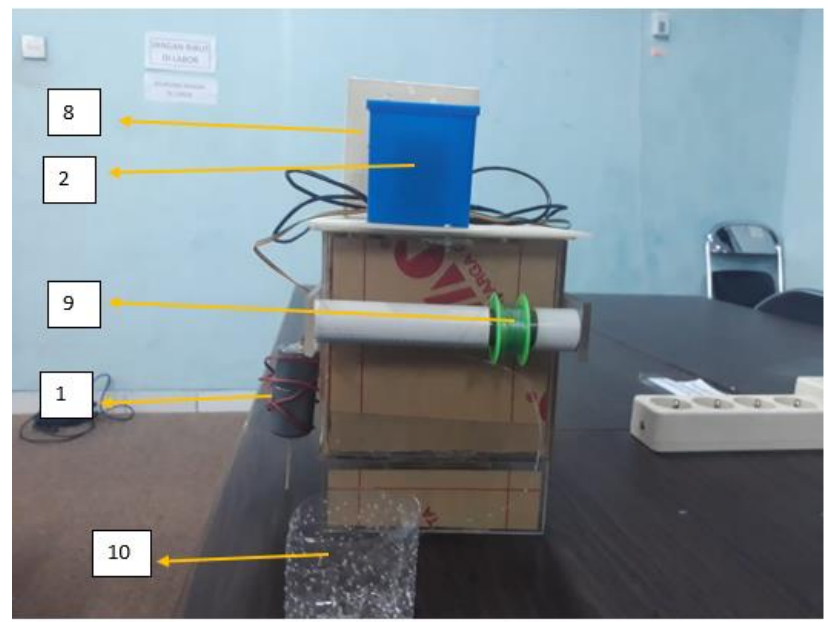

Gambar 19. Perangkat Keras Tampak Depan

Keterangan Gambar 17, Gambar 18, dan Gambar 19:

1. Sensor soil moisture digunakan untuk mengetahui kelembaban pada tanah. 
2. Sensor rain gauge digunakan untuk mengetahui tingkat curah hujan.

3. Potensiometer digunakan untuk mengetahui pergeseran tanah.

4. Modul GSM SIM800L digunakan sebagai media komunikasi

5. Arduino Uno digunakan untuk pengontrol perangkat keras.

6. Aki 12v digunakan untuk sumber daya.

7. RTC digunaan sebagai jam pada sistem .

8. Sirine digunakan untuk memberikan peringatan berupa suara.

9. Tali dan katrol sebagai pengubung antara potensiometer dengan beban katrol.

10. Beban katrol digunakan sebagai beban untuk menarik potensiometer ketika terjadi pergeseran tanah.

\section{Implementasi Perangkat Lunak}

Perangkat lunak yang digunakan pada Sistem Monitoring Tanah Longsor berbasis Internet of Thing dan Geographic Information System yaitu perangkat lunak untuk membangun sistem. Perangkat lunak yang digunakan adalah Arduino IDE.

Program yang tertanam pada sistem dibuat dengan menggunakan bahasa pemrograman C. Program meliputi data yang diterima oleh mikrokontroler dari sensor soil moisture, sensor rain gauge, dan potensiometer. Kemudian data yang diterima dikelola oleh mikrokontroler sebagai pembanding untuk menentukan tingkat kemungkinan longsor, berdasarkan hasil pengolahan dari mikrokontroler maka akan membuat sirine berbunyi ataupun tidak, dan data yang didapat akan dikirim menggunakan modul GSM SIM800L

\section{Pengujian Sistem}

Pengujian dan analisa sistem secara keseluruhan pada sistem monitoring kemungkinan tanah longsor ini dilakukan dengan cara mengaktifkan seluruh sistem dan menempatkan sistem pada bak pencobaan yang dilakukan di daerah Limau Manis. Pengujian ini ditujukan untuk mengetahui kemampuan sistem untuk mendeteksi kemungkinan terjadinya longsor.

Gambar 4.26, merupakan gambar pengujian sistem secara keseluruhan yang dilakukan secara simulasi pada bak pencobaan tanah. Saat sistem diaktifkan maka sistem akan melakukan pembaacaan data curah hujan, kelembaban tanah, dan pergeseran tanah, setelah input data dari sensor didapat mikrokontroler akan memproses data tersebut hingga didapat tingkat komungkinan longsor berstatus biasa atau waspada atau bahaya. kondisi di lapangan maka sistem akan mengirimkan pesan menggunakan SMS dan mengirim data ke thingspeak (database). Seperti yang terlihat pada Gambar 20 dan Tabel 1.

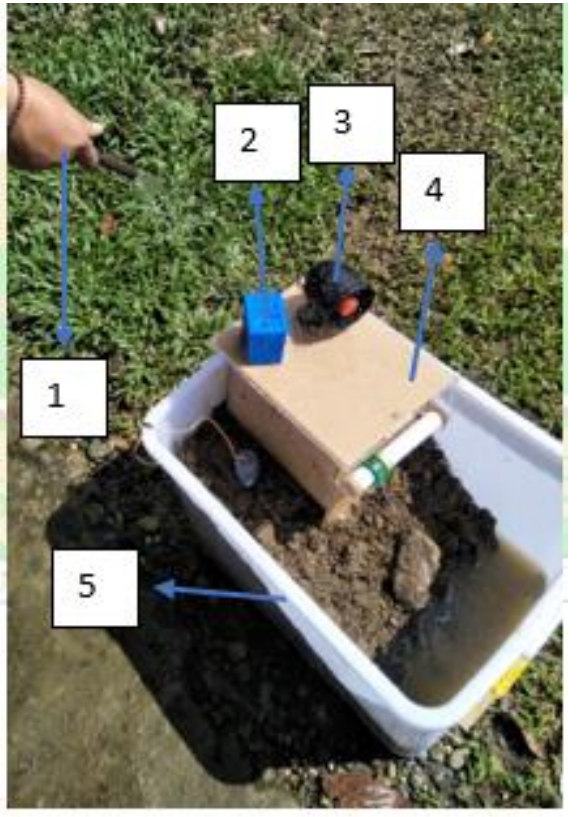

\section{Gambar 20. Pengujian Sistem}

Keterangan Gambar 20 :

1. Semprotan air yang digunakan untuk mensimulasikan hujan

2. Sensor rain gauge untuk menghitung curah hujan

3. Sirene untuk memberikan peringatan berupa suara

4. Kotak tempat komponen-komponen dirangkai.

5. Bak percobaan yang digunakan untuk simulasi.

Setelah dilakukan pengujian sebanyak sepuluh kali didapatkan hasil seperti Tabel 4.12. Berdasarkan tabel tersebut didapatkan bahwa pembacaan pergeseran terjauh yaitu $12,44 \mathrm{~cm}$ dan pergeseran terdekat yaitu $0,02 \mathrm{~cm}$, pembacaan kelembaban tanah terbesar yaitu $91,98 \%$ dan kelembaban tanah terkecil yaitu $0,49 \%$, dan pembacaan curah hujan terbesar yaitu $8,52 \mathrm{~mm}$ dan curah hujan terkecil yaitu $0,00 \mathrm{~mm}$.

Setelah dilakukan 10 kali percobaan didapatkan bahwa 8 kali percobaan dengan keterangan berhasil di selesaikan dengan baik dan 2 kali percobaan dengan keterangan tidak berhasil karena terjadi error pada pengiriman data dan data sensor tidak diketahui, error pada Tabel 1 menunjukkan bahwa data tidak terkirim, error tersebut dapat terjadi karena sinyal dari modul GSM SIM800L hilang atau lemah pada saat pengiriman sehingga data yang dikirim tidak masuk ke database. 
Persentase keberhasilan :

Persentase Keberhasilan $=\frac{(\text { jumlah percobaan berhasil })}{(\text { jumlah percobaan })}$ Persentase Keberhasilan $=\frac{8}{10} \times 100 \%$

Persentase Keberhasilan $=80 \%$

Tabel 1. Pengujian Sistem

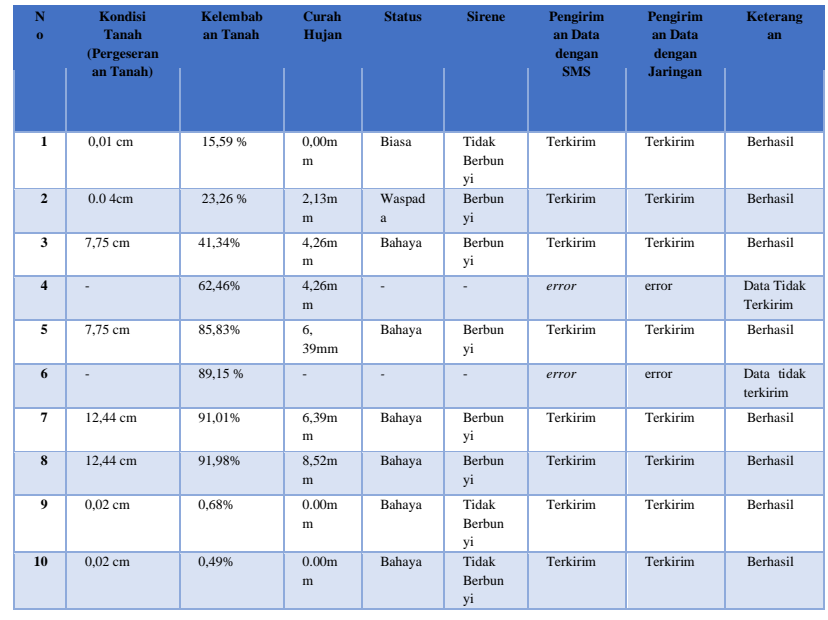

\section{KESIMPULAN}

Sistem ini dapat memperkirakan tingkat kemungkinan longsor berdasarkan tingkat curah hujan, kelembaban tanah, dan pergeseran tanah dan memberikan peringatan dengan tingkat keberhasilan $80 \%$. Sistem ini dapat dikembangkan lagi dengan menambah sensor pendekung untuk sistem sehingga sistem bisa lebih akurat dalam menetukan tingkat kemungkinan longsor.

\section{REFERENSI}

[1] Christady, Hary Hardiyatmo. 2012. Tanah Longsor dan Erosi. Gajah Mada University Press. Yogyakarta.

[2] Utama, Denya. 2017. Jalur Padang-Solok Tertimbun Longsor Di Lubuak Paraku. www.sumbar.antaranews.com. Edisi Oktober 2017.

[3] Artha, Onny Octaviani. 2018. Sistem Peringatan Dini Bencana Longsor Menggunakan Sensor Accelerometer dan Sensor Kelembaban Tanah Berbasis Android. Sistem Komputer. Universitas Andalas.

[4] Arduino

UNO, http://arduino.cc/en/Main/arduinoBoardUno, diakses pada tanggal 10 Maret 2018,Pukul 16.30 WIB.

[5] Evita, M, dkk.2010. Alat Ukur Curah Hujan TippingBucket Sederhana dan mudah berbasis Mikrokontroler. Vol 2(2),2010, Hal. 69-77. Institut Teknologi Bandung. Bandung.
[6] Asriya, Putri, Meqorry Yusfi. 2016. Rancang Bangun Sistem Monitoring Kelembaban Tanah Menggunakan Wireless Sensor Berbasis Arduino Uno. Jurnal Fisika Unand Vol. 5, No. 4, Oktober 2016. Jurusan Fisika, FMIPA, Universitas Andalas.

[7] Herawadi, Novi Sudibyo. 2017. Pendeteksi Tanah Longsor Menggunakan Sensor Cahaya. Jurnal TIM Darmajaya Vol. 01, 02 Oktober 2015, Hal 218-226. Institut Informatika dan Bisnis Darmajaya Bandar Lampung. Lampung.

[8] Ajie, Pulung Aribowo, dkk. Global System for Mobile Communication (GSM). Jurusan Teknik Elektro FT UGM. Yogyakarta.

[9] Prahasta, Eddy. 2009. Sistem Informasi Geagrafis: Konsep Konsep Dasar (Perspekti Geodesi \& Geomatika). Informatika Bandung. Bandung.

[10] Candra, Richard Nathaniel. 2014. Internet of Things dan Embedded System untuk Indonesia. Jurusan HumanComputer Interaction. Universitas Surya. Serpong

[11] Zubair, Aqmal. 2013. Sistem Peringatan Dini untuk Keamanan Rumah berbasis Mikrokontroler pada Kompleks Perumahan. Jurusan Informatika. UIN Alauddin Makassar.

[12] Sukriansyah, Edi, dkk. 2013. Prototipe Arduino Untuk Sistem Identifikasi Lokasi Berbasis GPRS. Seminar Nasional dan Expo Teknik Elektro 2013. Megister Teknik Elektro, Universitas Syiah Kuala.

[13] Karnawati, Dwikorita, dkk. 2010. Promoting a Model of research-based Education in disaster mitigation. J. SE Asian, Geol, Sep-Dec, Vol. 2(3), pp. 155-162. Gadjah Mada University, Yogyakarta, Indonesia.

[14] University, Yogyakarta, Indonesia. Modul GSM SIM 800. http://www.belajarduino.com/2016/05/sim8001-gsmgprsmodule-to arduino.html. Diakses tanggal 11 Maret 2018. Pukul 00.55 WIB.

[15] Presiden Republik Indonesia. UNDANG-UNDANG REPUBLIK INDONESIA NOMOR 24 TAHUN 2007 TENTANG PENANGGULANGAN BENCANA.

[16] Hidayat, Taufal. 2017. Sistem Pendeteksi Dini longsor menggunakan Teknologi Wireless Sensor Network (WSN). Institut Teknologi Padang. Padang.

[17] Faizana, Fina, dkk. 2015. Pemetaan Risiko Tanah Longsor Kota Semarang. Program Studi Teknik Geodesi, Fakultas Teknik, Universitas Diponegoro. Semarang.

[18] Indoware. 2015. Soil Moisture sensor, http://indoware.com/produk-284-moisture-sensor-html, diakses pada 10 maret 2018.

[19] Chay, Asdak. 2007. Hidrologi dan Pengelolaan Daerah Aliran Sungai. UNTAD Press. Gadjah Mada University. Yogyakarta. 